\title{
一定引張応力を受けながら繰り返しせん断応力を受ける
} 接着系あと施工アンカーの力学挙動と仕事量

\section{MECHANICAL BEHAVIOUR AND WORK OF ADHESIVE POST-INSTALLED ANCHORS SUBJECTED TO CYCLIC SHEAR FORCE AND CONSTANT TENSILE FORCE}

\author{
高瀬 裕也*1, 和田俊良 ${ }^{* 2}$, 池田隆明*3, 篠原保二*4, 溝口光男 *5 \\ Yuya TAKASE, Toshinaga WADA, Takaaki IKEDA, \\ Yasuji SHINOHARA and Mitsuo MIZOGUCHI
}

\begin{abstract}
A seismic retrofitting method that uses a newly-expanded frame has recently gained popularity. The joint in these structures are subjected to shear and tensile force during an earthquake. But, the behavior of post-installed anchors under combined forces remains unclear. Therefore, we conducted the shear tests subjected to tensile force constant. As a result, the shear force was decreased and the joint opening was increased as the tensile force increased. However, we found that the total work was almost constant even at varying tensile force. In addition, we proposed an estimation formula of the total work.
\end{abstract}

Keywords: Post-installed anchor, Seismic retrofitting, Combined force, Work あと施工アンカー, 而震補強, 組合せ応力, 仕事量

\section{1. はじめに}

既存建築物の耐震補強 ${ }^{1)}$ は，付加する耐震要素を既存架構の構面 内に取り付ける内付け補強と, 構面外に取り付ける外付け補強に大 別される。而震補強構造物において, 両工法ともに補強部材と既存 部材の接合が重要な要素の一つとなる。

外付け補強の例を Fig. 1 に示す。Fig. 1 からも理解できるように, 外付け補強構造物では，既存架構に対する補強部材の偏心が大きい ことから，この接合部は，地震時にせん断応力だけでなく，比較的 大きな曲げモーメントが作用する。これにより，接合部は引張応力 または圧縮応力を受けながら繰り返しせん断応力を負担することに なる。一般的な接合部では, 接着系あと施工アンカー（以下，本論 文で記述する「あと施エアンカー」は接着系あと施工アンカーを意 味する)が使用される。あと施工アンカーが引張応力を受けることで, せん断抵抗性能が低下寸ると考えられるが, 組合せ応力下の力学挙 動に関する知見が少ないのが現状である。実際の外付け補強の接合 部では, せん断応力に起因する偏心モーメントにより, 接合部に引 張応力が作用するため, せん断応力に応じた変動軸応力が作用する。 このため白井ら ${ }^{2)}$ や森下ら ${ }^{3)}$ は, アンカー筋を斜め方向に加力する 実験を行っている。しかし, これらの実験だけでは, アンカー筋径, コンクリート圧縮強度, さらには載荷履歴などの諸条件が限定され, 組合せ応力下のあと施工アンカーの力学的性質を論じるには不十分 なように思われる。

そこで本論文では，まずは組合せ応力下における基礎的な力学的

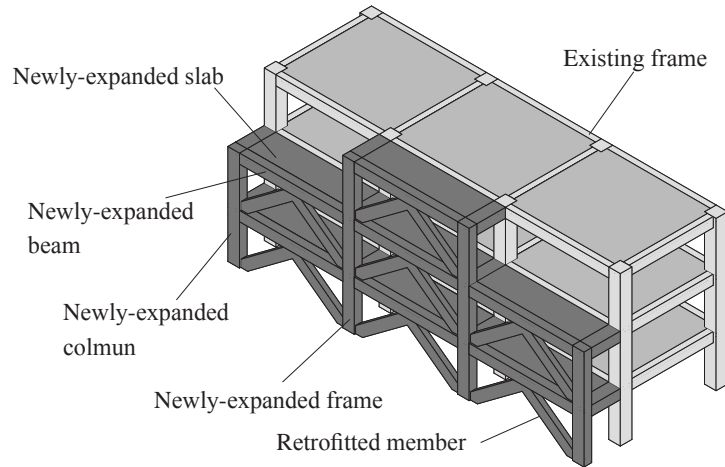

Fig.1 Image of seismic retrofitting method using newly-expanded frame

性質を把握するため, アンカー筋に一定引張応力を与えながら, 正 負交番の繰り返しせん断応力を与える実験を行う。また本研究の大 きな目的の一つに, 組合せ応力を受けるあと施工アンカーのせん断 応力と引張応力, およびずれ变形と目開き量の関係を結ぶ構成則を 構築することがある。そのため，これを達成する一つの手法として， あと施工アンカーが負担し得る仕事量に着目し実験結果を考察する。

\section{2. 本実験の概要}

Fig. 2 にせん断応力を受けるあと施工アンカーのせん断応力伝達 機構を示す。本実験で明らかにしたいのはせん断応力 $\mathrm{Q}$, 引張応力 $\mathrm{T}$, ずれ変形 $\delta_{\mathrm{S}}$, および目開量 $\delta_{\mathrm{N}}$ の 4 成分の相互関係である。本 2 章では,
*1 室蘭工業大学大学院工学研究科 $く ら し$ 環境系領域 准教授・博士 (工学)

*2 北海道職業能力開発大学校建築科 特任教授 - 博士 (工学)

*3 長岡技術科学大学環境社会基盤工学専攻 教授・博士(工学)

*4 東京工業大学未来産業技術研究所 准教授. 博士 (工学)

* 5 室蘭工業大学大学院工学研究科 $く ら し$ 環境系領域 教授・博士 (工学)
Assoc. Prof., College of Environmental Technology, Muroran Institute of Technology, Ph. D.

Prof., Dept. of Architecture, Hokkaido Polytechnic College, Dr. Eng.

Prof., Dept. of Civil and Environ. Eng., Nagaoka University of Technology, Dr. Eng. Assoc. Prof., Laboratory for FIRST, Tokyo Insutitute of Technology, Dr. Eng. Prof., College of Environmental Technology, Muroran Insutitute of Technology, Dr. Eng. 
これらを明らかにするための本実験の詳細を記述する。また, この せん断応力 $\mathrm{Q}$ は, 柱や梁の主筋のダウエル効果のようなメカニズム によって生じる応力, つまりアンカー筋の曲げ応力やコンクリート の支圧応力が複合して生じるものであるが，本論文ではこれらの水 平方向の応力をせん断応力と呼称する。

\section{1 試験体パラメータ}

Table1 に試験体パラメータを示す。本論文では全 13 体の試験体 の載荷実験を行う。試験体パラメータは，1) アンカー筋径 $\phi, 2)$ 一 定引張応力 $\sigma_{N}$ (引張荷重をアンカー筋の有効断面積で除した值 ), 3) コンクリート圧縮強度 $\sigma_{\mathrm{B}}$ である。アンカー筋は，実際の耐震補強で よく使用されるD13，D16，D19の 3 種類の異形棒鋼（頂部のみネジ 加工を施したものであり材質は全て SD 345 である）とし，一定引張 応力 $\sigma_{\mathrm{N}}$ は $0 \mathrm{~N} / \mathrm{mm}^{2}$ に加え, アンカー筋の降伏強度 $\sigma_{\mathrm{y}}$ のおよそ $1 / 3$, $2 / 3$ 倍の 3 段階とする。以後, 引張応力を示す指標として, $\sigma_{N}$ の $\sigma_{y}$ に対する引張応力比 $r_{N}\left(\sigma_{N} / \sigma_{y}\right)$ を用いる。 $\sigma_{\mathrm{B}}$ は $10 \sim 30 \mathrm{~N} / \mathrm{mm}^{2}$ の範

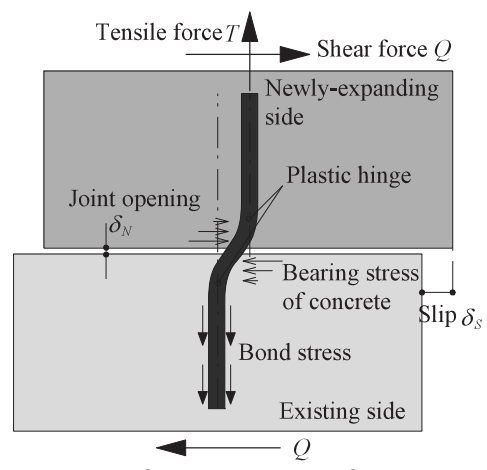

Fig.2 Shear stress transfer mechanism of post-installed anchor

Table 1 Specimen parameters

\begin{tabular}{cccccc}
\hline $\begin{array}{c}\text { Specimen } \\
\text { No. }\end{array}$ & $\begin{array}{c}\phi \\
(\mathrm{mm})\end{array}$ & $\mathrm{r}_{N}$ & $\begin{array}{c}\mathrm{F}_{\mathrm{c}} \\
\left(\mathrm{N} / \mathrm{mm}^{2}\right)\end{array}$ & $\begin{array}{c}\mathrm{L}_{\mathrm{e}} \\
(\mathrm{mm})\end{array}$ & $\begin{array}{c}\text { Grouting } \\
\text { mortal }\end{array}$ \\
\hline D13-T000-20 & 13 & 0 & 20 & $10 \phi$ & Property-1 \\
\hline D13-T033-20 & 13 & 0.33 & 20 & $10 \phi$ & Property-1 \\
\hline D13-T066-20 & 13 & 0.66 & 20 & $10 \phi$ & Property-1 \\
\hline D 16-T000-10 & 16 & 0 & 10 & $10 \phi$ & Property-2 \\
\hline D16-T056-10 & 16 & 0.56 & 10 & $10 \phi$ & Property-2 \\
\hline D 16-T000-20 & 16 & 0 & 20 & $10 \phi$ & Property-1 \\
\hline D 16-T033-20 & 16 & 0.33 & 20 & $10 \phi$ & Property-1 \\
\hline D 16-T066-20 & 16 & 0.66 & 20 & $10 \phi$ & Property-1 \\
\hline D16-T000-30 & 16 & 0 & 30 & $10 \phi$ & Property-2 \\
\hline D 16-T056-30 & 16 & 0.56 & 30 & $10 \phi$ & Property-2 \\
\hline D 19-T000-20 & 19 & 0 & 20 & $10 \phi$ & Property-1 \\
\hline D 19-T033-20 & 19 & 0.33 & 20 & $10 \phi$ & Property-3 \\
\hline D 19-T066-20 & 19 & 0.66 & 20 & $10 \phi$ & Property-1 \\
\hline
\end{tabular}

$\phi$ : Diameter of anchor bolt, $r_{N}:$ Ratio of $\sigma_{y}$ and $\sigma_{N}, \sigma_{y}: Y$ ield strength, $\sigma_{N}:$ Tensile stress, $F_{c}$ : Design compressive strength of concrete, $E_{c}: Y$ oung's modulus of concrete, $L_{e}$ : Embedded length of anchor bolt
囲で 3 段階に設定する。なお， $\sigma_{B}$ が $10 \mathrm{~N} / \mathrm{mm}^{2}$ と $30 \mathrm{~N} / \mathrm{mm}^{2}$ を目標と した試験体については，試験体数の関係から $\mathrm{r}_{N}$ を2段階にしか設定 できなかったため， $r_{N}=0$ と， 0.33 および 0.66 のおよ中間の $r_{N}=0.56$ とした。試験体名は, 始めに $\phi$ を, 次に $\mathrm{r}_{N}\left(033\right.$ は $\mathrm{r}_{N}=0.33$ を意味する) を，最後に目標とする $\sigma_{\mathrm{B}}$ を意味する数值を組合せて構成される。ア ンカー筋の有効埋め込み深さは全て $10 \phi$ である。

また，大きく 3 期間に分けて載荷実験を行っていることか ら, Table1には，グラウトの材料特性として各載荷期間に応じ, Property-1 3の3 種類を示している。

\section{2 試験体形状}

Fig. 3 に試験体の諸元寸法を, Table2 にコンクリートとグラウト の材料特性を，Table3 にアンカー筋の機械的性質を示す。Table2 に 示している 3 種類のグラウトは, Table1 の Property-1 3 にそれぞれ 対応している。

本試験体は，外付け補強のうち鉄骨枠付きブレースを用いた直付 け工法 ${ }^{4)}$ における，既存躯体から接合部までの一部を模擬したもの である。既存躯体に相当するコンクリート部分は，幅 $400 \mathrm{~mm}$ ，長さ $440 \mathrm{~mm}$ ，高さ $250 \mathrm{~mm}$ ，接合部に相当する増設側は，幅 $160 \mathrm{~mm}$ ，長さ $350 \mathrm{~mm}$ ，高さ $170 \mathrm{~mm}$ である。コンクリート部分にアンカー筋を定着 した後に，接合面にグリスを塗布し，2-中19 のスタッドを溶接した鋼 板と割裂防止筋として鉄筋籠を設置し，接合面と鋼板の間にグラウ 卜を圧入する。グリスを塗布する理由は，引張応力導入時のグラウ トとコンクリートの付着（または接着）応力の影響や，せん断載荷 時の接合面の摩擦抵抗の影響を出来る限り小さくするためである。

近年の耐震補強工事では，建物を使用しながらの施工が要求され ることが多いため，あと施工アンカーの施工に際し，穿孔工具に湿 式コアドリルを使用し，エポキシ系の注入型接着剤でアンカー筋を 定着する工法を採用する。文献 5) では，本試験体で採用している工

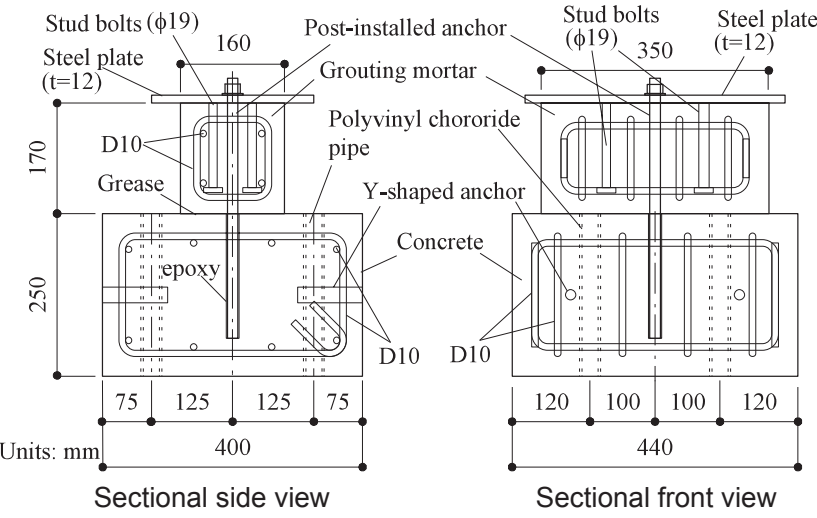

Fig.3 Details of specimen

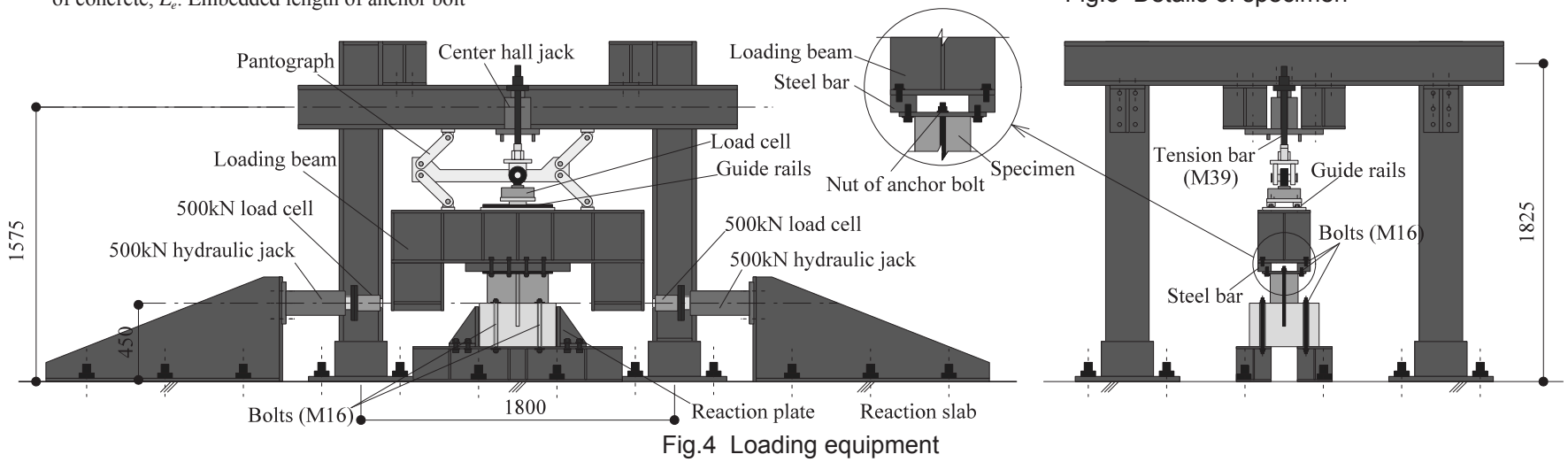


法と同様のあと施エアンカーを対象とした付着実験の結果が報告さ れている。この付着実験の結果を観察すると, 一般的な工法(ハンマー ドリルによって穿孔し, カプセル型の接着剂を用いて定着例えば6) する 工法）と比べ，特段に大きな違いがないように判断される。このた め著者らは, 以下に展開する論述を一般的な工法にも適用し得ると 考えているが，工法の違いによる影響は今後の課題としたい。

また増設部へのアンカー筋の定着方法として, 鋼板からアンカー 筋に確実に引張応力が伝達するよう, 鋼板に孔を設けアンカー筋を ナット締めする。さらに全てのアンカー筋には，せん断応力方向前 後の断面 2 箇所に $2 \mathrm{~mm} \times 2 \mathrm{~mm}$ の溝を設けひずみゲージを貼る。ゲー ジを貼り付ける高さは，接合面およびそこから上下に $2 \phi$ の位置であ り, 加力方向の前後に各 2 枚, 計 6 箇所で主にひずみを計測する。なお, D13-T033-20 および D19-T033-20の 2 体のみ, ゲージ枚数の都合から ひずみを計測していない。

\section{3 加力方法}

Fig. 4 に本実験の加力装置を示す。加力装置には, せん断載荷用 に 2 本の $500 \mathrm{kN}$ 油圧ジャッキを,引張載荷用にセンターホールジャッ キを用いる。センターホールジャッキに挿入する PC 鋼棒の下端に ロードセルを設置し, これをガイドレールを介してコの字型加力ビー ム (Loading beam) に固定する。またコの字型加力ビームを, 平行ク ランク（Pantograph）を用いて加力フレームに固定することで，せん 断載荷時に出来るだけ平行に変位するように配慮する。加力ビーム と平行クランクの総重量は $3.88 \mathrm{kN}$ であり, $\mathrm{r}_{N}=0$ の試験体にはこの分 だけ圧縮荷重が作用する。

試験体に引張応力とせん断応力を与えるため, 試験体上部に設置 した鋼板を，コの字型加力ビームにボルト締めする。ここで，アン カー筋頂部のナットが干渉しないように, Fig. 4 の中央上部に示寸

Table 2 Material properties of concrete and grouting mortal

\begin{tabular}{cccc}
\hline & $\begin{array}{c}\sigma_{\mathrm{B}} \\
\left(\mathrm{N} / \mathrm{mm}^{2}\right)\end{array}$ & $\begin{array}{c}\mathrm{E}_{\mathrm{c}} \\
\left(\mathrm{kN} / \mathrm{mm}^{2}\right)\end{array}$ & $\begin{array}{c}\sigma_{\mathrm{t}} \\
\left(\mathrm{N} / \mathrm{mm}^{2}\right)\end{array}$ \\
\hline $\mathrm{F}_{\mathrm{c}}=10 \mathrm{~N} / \mathrm{mm}^{2}$ & 12.5 & 18.1 & 1.43 \\
\hline $\mathrm{F}_{\mathrm{c}}=20 \mathrm{~N} / \mathrm{mm}^{2}$ & 20.1 & 23.8 & 1.93 \\
\hline $\mathrm{F}_{\mathrm{c}}=30 \mathrm{~N} / \mathrm{mm}^{2}$ & 30.5 & 25.9 & 1.93 \\
\hline Grouting mortal-1 & 59.1 & 23.6 & 3.30 \\
\hline Grouting mortal-2 & 70.7 & 24.6 & 3.00 \\
\hline Grouting mortal-3 & 72.6 & 23.4 & 3.28 \\
\hline
\end{tabular}

$\sigma_{\mathrm{B}}$ : Compressive strength, $\mathrm{E}_{\mathrm{c}}:$ Young's modulus, $\sigma_{\mathrm{t}}:$ Splitting strength

Table 3 Material properties of anchor bolts

\begin{tabular}{ccccc}
\hline $\begin{array}{c}\phi \\
(\mathrm{mm})\end{array}$ & $\begin{array}{c}\sigma_{\mathrm{y}} \\
\left(\mathrm{N} / \mathrm{mm}^{2}\right)\end{array}$ & $\begin{array}{c}\sigma_{\mathrm{u}} \\
\left(\mathrm{N} / \mathrm{mm}^{2}\right)\end{array}$ & $\begin{array}{c}\mathrm{E}_{\mathrm{s}} \\
\left(\mathrm{kN} / \mathrm{mm}^{2}\right)\end{array}$ & $\begin{array}{c}\delta \\
(\%)\end{array}$ \\
\hline 13 & 375 & 582 & 193 & 26 \\
\hline 16 & 396 & 582 & 194 & 24 \\
\hline 19 & 402 & 600 & 189 & 23
\end{tabular}

$\phi$ : Diameter of anchor bolt, $\sigma_{\mathrm{y}}: \mathrm{Y}$ ield strength, $\sigma_{\mathrm{u}}$ : Ultimate strength, $\mathrm{E}_{\mathrm{s}}$ : Young's modulus of anchor bolt, $\delta$ : Elongation after fracture

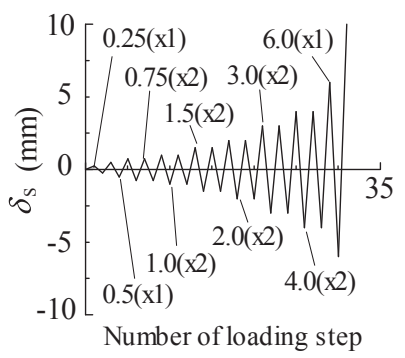

Fig.5 Loading steps

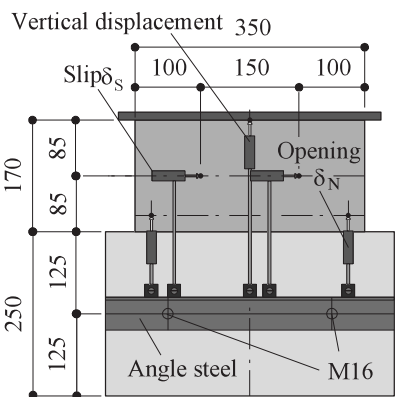

Fig.6 Details of measurments
通りコの字型加力ビームと鋼板の間に, M 16 のタップを切った厚さ $50 \mathrm{~mm}$ の鉄板（Steel bar）を挟み，高力ボルトを用いて連結している。 試験体のコンクリート部分には，4 本の塩ビ管を埋め込んでおり，こ こにM16の高力ボルトを通して, 試験体を加カフレームに固定し, 引張応力に対する反力を得る。

Fig. 5 に載荷サイクルを示す。外付け補強の設計で一般に用いら れる指針 ${ }^{4)}$ によれば，「接合部のずれ変形 $\delta_{\mathrm{s}}$ を $2 \mathrm{~mm}$ 以内に抑えるこ と」とされている。本実験では, この許容值の 3 倍となる $\delta_{\mathrm{s}}=6 \mathrm{~mm}$ までを主たる実験対象範囲とすることで，構造物に過大な外力が作 用する（過大な変形が生じる）場合に対しても，適切に評価できる ように配慮する。そこで， $\delta_{\mathrm{S}}=0.5 \mathrm{~mm}$ 以下で正負 1 回づつ，その後， $\delta_{\mathrm{s}}=4.0 \mathrm{~mm}$ まで 2 サイクルづつ載荷し, $\delta_{\mathrm{s}}=6.0 \mathrm{~mm}$ を 1 サイクル, 最 後は正側に押し切る載荷サイクルとする。

\section{4 計測方法}

Fig. 6 に本実験の計測方法を示す。試験体の既存側コンクリートの 高さ中央の位置に, インサートを 2 箇所埋め込み，これに $50 \mathrm{~mm} \times$ $50 \mathrm{~mm}$ のアングルを固定する。ここにマグネットスタンドを用いて 変位計を固定し，グラウトに設置したターゲットの相対水平変位と 相対鉛直変位を 2 箇所づつ計測し，それぞれの平均值をずれ变形 $\delta \mathrm{s}$ と目開き量 $\delta_{N}$ とする。引張荷重は，PC 鋼棒に取り付けたロードセ ルの值とし，せん断荷重も水平方向に配置した油圧ジャッキに取り 付けたロードセルの值として計測する。

\section{3. 実験結果}

\section{1 せん断応力 -ずれ変形曲線}

Fig. $7(\mathrm{a}) \sim(\mathrm{m})$ に, 各試験体のせん断応力 $\mathrm{Q}-$ ずれ変形 $\delta_{\mathrm{s}}$ 曲線 を示す。アンカー筋のひずみを計測した試験体については，白丸で 降伏ひずみに達した点を示している。ここでは, 6 枚のゲージのうち， いずれか最初に降伏ひずみに達した点をプロットしている。

はじめに, $\phi=13 \mathrm{~mm}$ とした Fig. 7 (a) 〜 (c) の実験結果に着目する。 Fig. 7 (a) に示す $r_{N}=0$ である D13-T000-20 の Q- $\delta_{S}$ 曲線を観察すると， $\delta_{\mathrm{s}}=+0.75 \mathrm{~mm}$ で一度ピークに達し, その後はやや応力が低下するが, この応力を維持しながら変形が進展する。最終ステップの押切り載 荷において, 再び応力が増加する。これに対し一定引張応力を与えた, Fig. 7 (b) の D 13-T033-20，および同図 (c) のD13-T066-20の Q- $\delta_{\mathrm{S}}$ 曲 線も，全体的な傾向はD13-T000-20 と同様である。しかしながら， せん断応力は引張応力が大きい試験体ほど低下する。

続いて， $\sigma_{B}=20.1 \mathrm{~N} / \mathrm{mm}^{2}$ で， $\phi=16 \mathrm{~mm}$ および $19 \mathrm{~mm}$ とした Fig. 6 (f) 〜 (h) および $(\mathrm{k}) 〜(\mathrm{~m})$ の実験結果を観察する。Fig. 6(f) および $(\mathrm{k})$ に示す, $\mathrm{r}_{N}=0$ としたD16-T000-20およびD19-T000-20において，そ れぞれ $\delta_{\mathrm{S}}=+0.75 \mathrm{~mm}$ と $\delta_{\mathrm{S}}=+1.5 \mathrm{~mm}$ の載荷ステップで, 一度ピークに 達し, その後やや応力低下寸るが, その後ずれ変形の増大に伴い応 力が再び増加する傾向は，先に触れた D13-T000-20 と同様である。 また， $\mathrm{r}_{\mathrm{N}}$ の増大につれ，せん断応力が小さくなる特徵も同じである。

アンカー筋が降伏する条件について, 正側または負側のどちらで 降伏するかは, 明快な規則性はないようであるが, $r_{N}=0$ では $\pm 0.75 \mathrm{~mm}$ 前後, $r_{N}=0.56 \sim 66$ の場合は, $\pm 0.5 \mathrm{~mm}$ 以内の小さい変形領域で降伏 ひずみに達している。

最後に, $\phi=16 \mathrm{~mm}$ でコンクリート圧縮強度 $\sigma_{\mathrm{B}}$ を $12.5,20.1$ およ び $30.5 \mathrm{~N} / \mathrm{mm}^{2}$ と 3 段階に違えた試験体の結果を観察する。これを検 


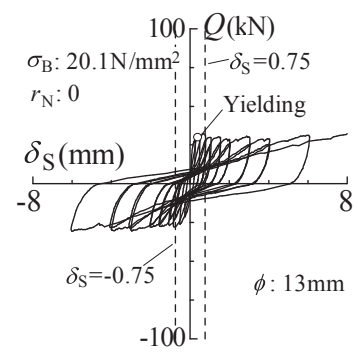

(a) D13-T000-20

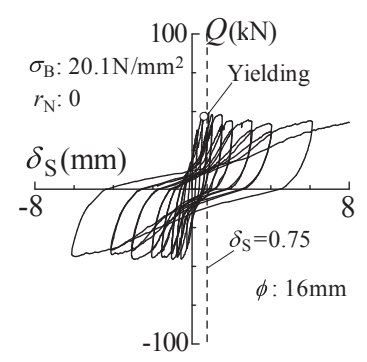

(f) D 16-T000-20

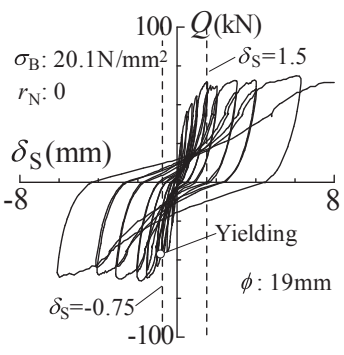

(k) D 19-T000-20

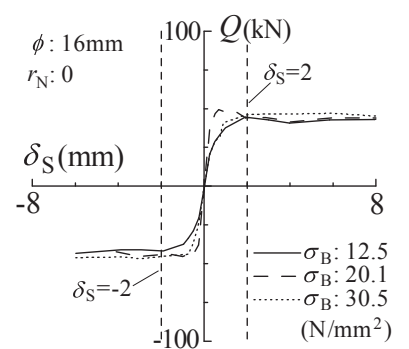

(a) $r_{N}=0$

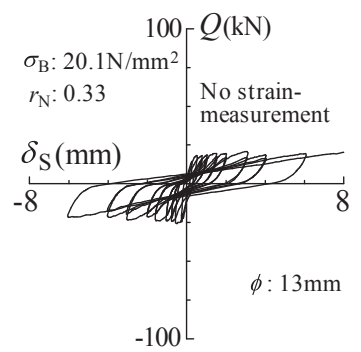

(b) D 13-T033-20

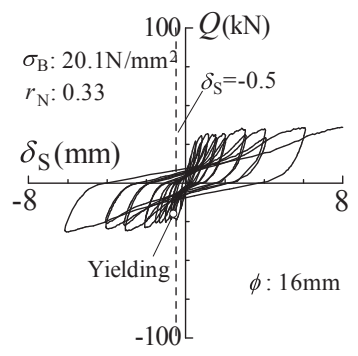

(g) D 16-T033-20

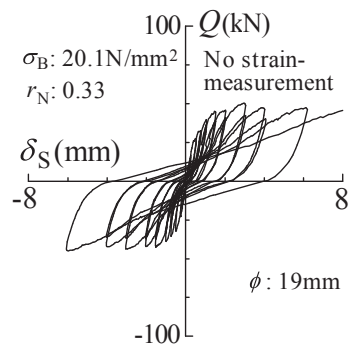

(I) D 19-T033-20

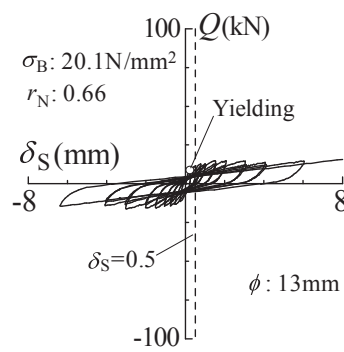

(c) D 13-T066-20

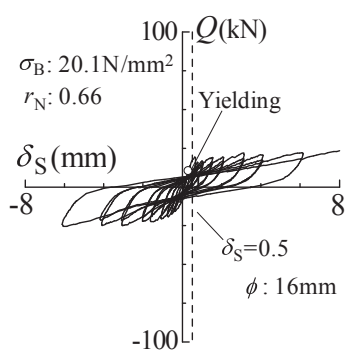

(h) D 16-T066-20

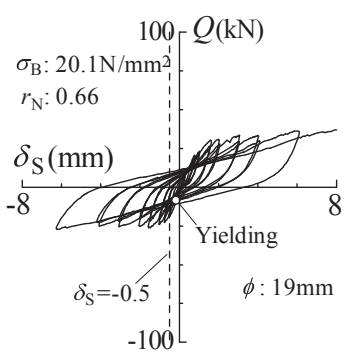

(m) D 19-T 066-20

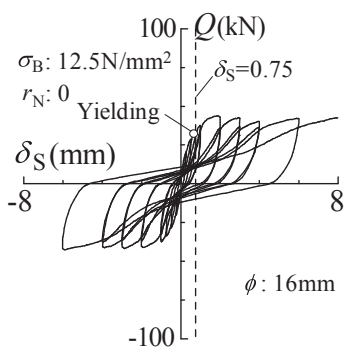

(d) D 16-T000-10

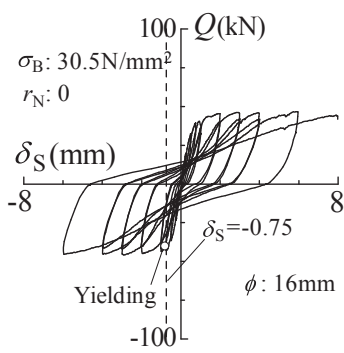

(i) D 16-T000-30

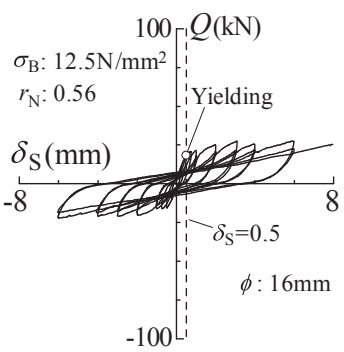

(e) D 16-T 056-10

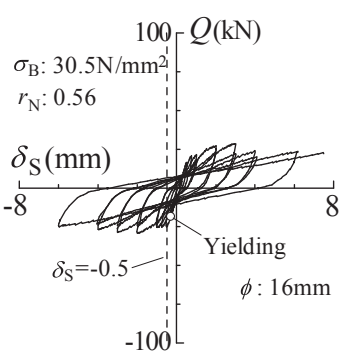

(j) D 16-T056-30

Fig.7 Load-Slip curves

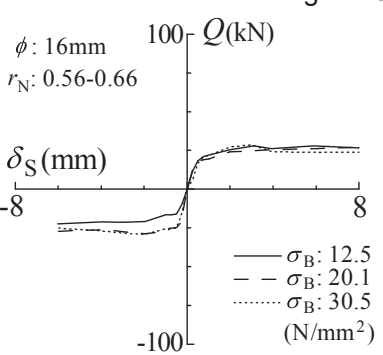

(b) $r_{N}=0.56,0.66$

Fig. 8 Comperison of envelope curves in specimens of defferent $\sigma_{B}$

証するためには，Fig.7(d)，（e），(f)，（h），（i）および（j）を観察 すれば良いが，より容易に $\sigma_{\mathrm{B}}$ による違いを比較できるよう, Fig. 8 にこれらの試験体の包絡曲線を比較した結果を示す。Fig. 8(a) に は $\mathrm{r}_{N}=0$, Fig. 8(b) には $\mathrm{r}_{N}=0.56,0.66$ の試験体の結果を示している。 Fig. 8 (a) より, $\delta_{\mathrm{s}}=-2.0 \sim 2.0 \mathrm{~mm}$ の変形領域で, $\sigma_{\mathrm{B}}=20.1 \mathrm{~N} / \mathrm{mm}^{2}$ の試験 体のせん断応力がやや高めになっている以外, 全体的な傾向として は, $\sigma_{\mathrm{B}}$ が大きい方がせん応力の值も大きくなっている。しかしながら, その大きさの違いは僅かなものである。次に Fig. 8(b) を観察すると, 正側については，3 試験体ともほとんど同じような挙動を示してお り, 負側については $\sigma_{B}=12.5 \mathrm{~N} / \mathrm{mm}^{2}$ の試験体がやや小さいせん断応力 となっている。したがって, Fig. 8 に示した結果を総じて述べれば, 本論文における $\sigma_{\mathrm{B}}=12.5 \sim 30.5 \mathrm{~N} / \mathrm{mm}^{2}$ の範囲では, せん断応力に対し 顕著な違いは見られなかったと言えよう。

\section{2 目開き量の推移}

Fig. $9(\mathrm{a}) \sim(\mathrm{m})$ に, 各試験体の目開き量 $\delta_{\mathrm{N}}-$ ずれ変形 $\delta_{\mathrm{S}}$ 曲線を示 す。また Fig. 7 と同様にアンカー筋のひずみを計測した試験体につ

いては，白丸で降伏ひずみに達した点を示している。

はじめに, $\phi=13 \mathrm{~mm}$ とした Fig. $9(\mathrm{a}) \sim(\mathrm{c})$ の $\delta_{\mathrm{N}}{ }^{-} \delta_{\mathrm{s}}$ 曲線に着目す る。これらの図を観察すると明らかなように, 引張応力が大きい試 験体の方が目開き量も大きくなる。 $\mathrm{r}_{N}=0$ であるD13-T000-20 では, $\delta_{\mathrm{s}}= \pm 6 \mathrm{~mm}$ まで載荷しても, 目開き量は $1 \mathrm{~mm}$ 程度に納まる。しか し, $\mathrm{r}_{N}=0.33$ とした D13-T033-20 では, $\delta_{\mathrm{S}}=+3 \mathrm{~mm}$ で $\delta_{\mathrm{N}}$ が $1 \mathrm{~mm}$ を超え, $\mathrm{r}_{N}=0.66$ とした D13-T066-20 においては， $\delta_{\mathrm{S}}=+2 \mathrm{~mm}$ 手前で $1 \mathrm{~mm}$ を超 える。また $\delta_{\mathrm{N}}$ の挙動に着眼すると, D 13-T000-20 と D 13-T033-20では, $\delta_{\mathrm{S}}$ が小さい範囲で, せん断荷重の除荷時に， $\delta_{\mathrm{N}}$ がある程度元に戻る （目開きが閉じる）挙動が確認され， $\delta_{\mathrm{S}}\left(\right.$ または $\delta_{\mathrm{N}}$ ）がある值を超え ると, 除荷時の $\delta_{\mathrm{N}}$ の残留が大きくなり, その後は漸増的に目開いて いく。これに対し, D13-T066-20は, $\delta_{\mathrm{s}}$ が小さい範囲から, 除荷時 の $\delta_{\mathrm{N}}$ の残留が大きく, 繰り返しせん断載荷とともに $\delta_{\mathrm{N}}$ が大きくなっ ていく。さらに, D13-T066-20を詳細に観察すると, 同変形時であっ ても， 2 回目のサイクルの方が，目開きが大きくなっている。この傾 向は, $\phi$ を $16 \mathrm{~mm}$ および $19 \mathrm{~mm}$ とした試験体でも同じである。したがっ て, 引張応力下における接合部の目開き量は, ずれ変形量, 引張応 力比および載荷サイクル数に依存する。ただし，載荷サイクル数の 影響については, より多くの繰り返し載荷を与える実験を行うなど, 検討の余地があり, 今後の研究課題としたい。

次に, 改めて $\sigma_{B}=20.1 \mathrm{~N} / \mathrm{mm}^{2}$ で, $\phi$ を $16 \mathrm{~mm}$ および $19 \mathrm{~mm}$ とした Fig. 9(f) 〜 (h) および $(\mathrm{k}) \sim(\mathrm{m})$ の実験結果を観察する。これらの 図より, $\phi$ が異なっても, 基本的な傾向は $\phi=13 \mathrm{~mm}$ とした試験体の 結果と同じであり, また目開き量の值自体も, 各アンカー筋径で多 少の違いはあるが， $r_{\mathrm{N}}$ に応じてほぼ同程度の值を示している。 


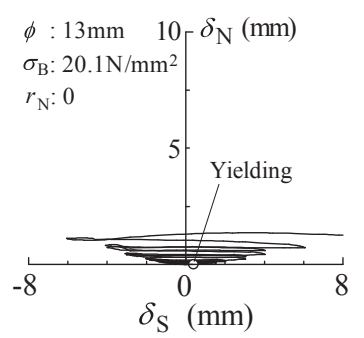

(a) D $13-\mathrm{T} 000-20$

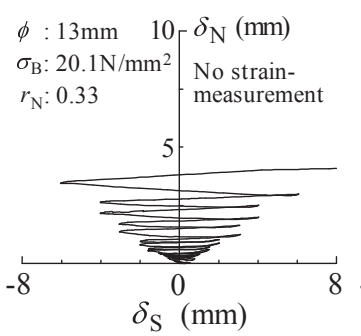

(b) D 13-T033-20

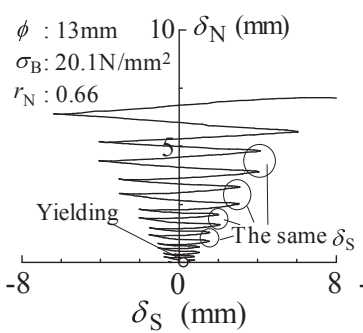

(c) D 13-T 066-20

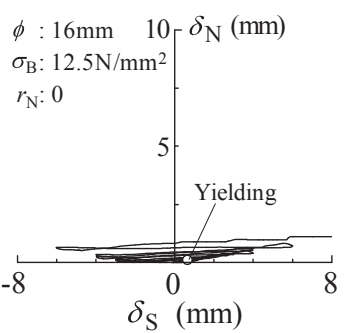

(d) D 16-T 000-10

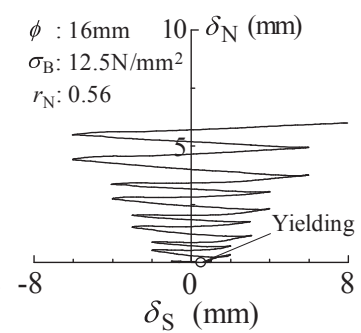

(e) D 16-T 056-10

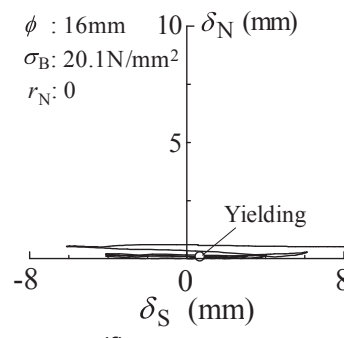

(f) D $16-T 000-20$

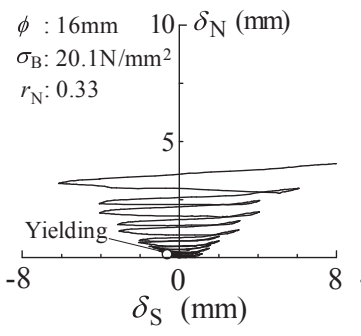

(g) D 16-T033-20

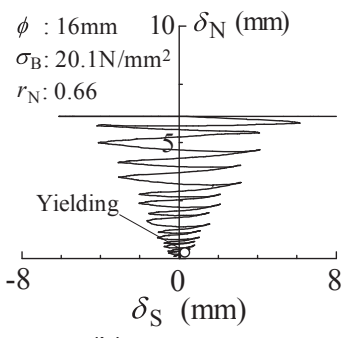

(h) D 16-T066-20

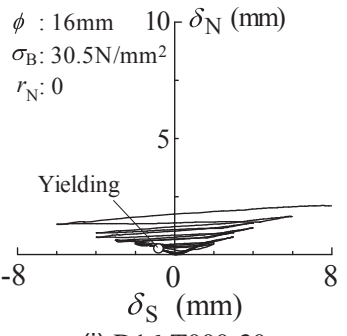

(i) D 16-T000-30

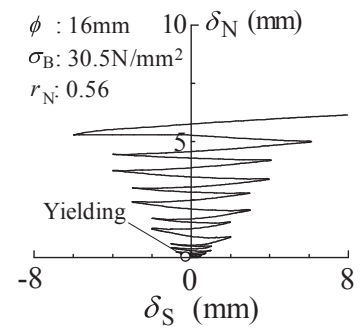

(j) D16-T056-30

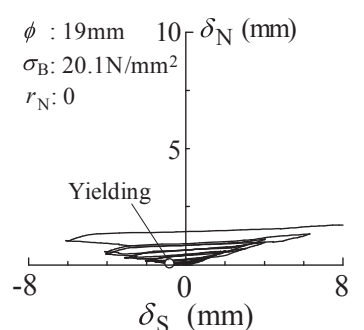

(k) D 19-T000-20

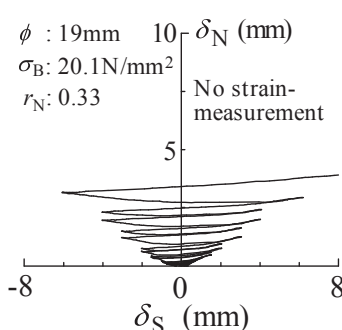

(I) D 19-T033-20

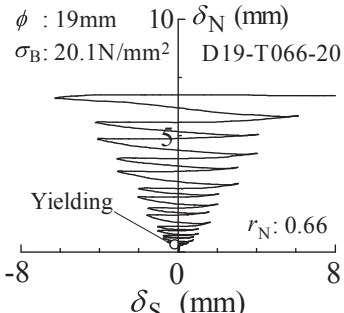

(m) D 19-T066-20

Fig.9 Joint opening-Slip curves

続いて $\phi=16 \mathrm{~mm}$ で， $\sigma_{\mathrm{B}}$ が異なる試験体の結果を示した Fig. 9 (d), (e)，(f)，（h），（i）および (j)の $\delta_{\mathrm{N}}-\delta_{\mathrm{s}}$ 曲線に着目する。 $\mathrm{r}_{N}=0$ では, $\sigma_{\mathrm{B}}=30.5 \mathrm{~N} / \mathrm{mm}^{2}$ の試験体がやや大きめの $\delta_{\mathrm{N}}$ を示すが, 残りの 2 体は ほぼ同じ值を示している。しかし， $\mathrm{r}_{N}$ が 0.6 程度の試験体では, い ずれも同程度の推移を示している。以上から, 前項の $\mathrm{Q}-\delta_{\mathrm{s}}$ 曲線と同 様に, $\delta_{\mathrm{N}}-\delta_{\mathrm{S}}$ 曲線についても, $\sigma_{\mathrm{B}}=12.5 \sim 30.5 \mathrm{~N} / \mathrm{mm}^{2}$ の範囲では $\sigma_{\mathrm{B}}$ の 違いによる顕著な相違は確認されない。

また $\mathrm{r}_{N}=0$ の試験体でも目開きが確認される。この理由として,ず れ変形によるアンカー筋の曲げひずみや付着による抜け出しの影響 等が考えられるが, この現象の解明は今後の研究課題としたい。

\section{3 引張応力がせん断応力に及ぼす影響}

Fig. 10 に, 軸応力比一せん断応力比関係を示寸。

組合せ応力を受ける延性材料を評価する際の代表的な方法の一つ として, Mises 応力による評価が挙げられる。しかしながら, 既述し たように本論文で論じているせん断応力は, 純粋なせん断応力では なく, アンカー筋の曲げ応力や, コンクリートおよびグラウトの支 圧応力を含む複合的な応力である。また，白井らの論文に対する討 論 $^{71,8)}$ においても, 同様の応力場が M ises 応力を適用するための境界 条件と異なることが議論されており, 本実験結果の評価に M ises 応 力を適用寸るのは困難なように思われる。そこで本論文では, 一般 に組合せ応力を受ける構造部材の設計で用いられる式 (1) 例えば4) から, 本実験結果を考察する。

$$
\left(\frac{T}{T_{a}}\right)^{\alpha}+\left(\frac{Q}{Q_{a}}\right)^{\alpha}=1
$$

ここに $\alpha$ は係数であり1 2 の間に設定される。Tと Q
れ組合せ応力下において負担可能な引張応力とせん断応力である。 また, $\mathrm{T}_{\mathrm{a}}$ は $\mathrm{Q}=0 \mathrm{kN}$ における許容引張応力, $\mathrm{Q}_{\mathrm{a}}$ は $\mathrm{T}=0 \mathrm{kN}$ における許 容せん断応力である。 $T_{a}$ はアンカー筋が引張降伏する際の強度とな ることから, 次式によって求められる注1)

$$
T_{a}=\sigma_{y} \times A_{s}
$$

ここに $\mathrm{A}_{\mathrm{s}}$ はアンカー筋（異形棒鋼）の有効断面積である。

また $\mathrm{Q}_{\mathrm{a}}$ については，通常は上記の通り $\mathrm{T}=0 \mathrm{kN}$ の許容せん断応力 であり，換言すれば $\mathrm{Q}_{\mathrm{a}}$ はせん断耐力である。しかし，本論文で対象 としている $\delta_{\mathrm{s}}=6 \mathrm{~mm}$ までの範囲では, せん断耐力に達しない可能性 があり，また（引張降伏強度と異なり）せん断耐力は実験值と計算 值のばらつきが大きい。そこで，本論文では $\mathrm{Q}_{\mathrm{a}}$ の代わりに $\exp _{0}$ と して， $r_{\mathrm{N}}=0$ とした試験体における $\mathrm{Q}$ の值を用いる。これにより， $\mathrm{r}_{\mathrm{N}}$ $=0$ の試験体と引張応力を与えた試験体の実験結果を直接比較するこ とで， $\mathrm{r}_{\mathrm{N}}$ の大きさによる Q の低下量を定量的に評価できる。Fig. 10 には, $\delta_{\mathrm{s}}=0.25,0.5,1.0,2.0,4.0$ および $6.0 \mathrm{~mm}$ における軸応力比（ $\mathrm{T} /$ $\left.\mathrm{T}_{\mathrm{a}}\right)$ とせん断応力比 $\left(\mathrm{Q} /\right.$ exp $\left._{0}\right)$ の関係を示している。加えて同図には $\alpha=0.75 ， 1 ， 1.2$ および 1.5 とした式 (1) による曲線も併記している。

Fig. 10 より実験条件の違いによりバラッキはあるものの, $\alpha=0.75$ ～ 1.5 とすることで, 組合せ応力時の負担せん断応力と負担引張応力 を凡そ評価できる。また，一概には言えないが， $\delta_{\mathrm{s}}=0.25 \mathrm{~mm}$ や $0.5 \mathrm{~mm}$ の小さい変形領域では $\alpha=0.75 \sim 1$ の間に, 反対に $\delta_{\mathrm{s}}=1.0 \mathrm{~mm}$ を超えた 範囲では $\alpha=1 \sim 1.5$ の間に実験值が納まることが確認される。仮に, 組合せ応力時でも, 負担し得る応力が変わらないとすれば, Fig. 10 において，原点を中心とし $\mathrm{T} / \mathrm{T}_{\mathrm{a}}=1$ と $\mathrm{Q} / \mathrm{Q}_{\mathrm{a}}=1$ を結ぶ円 $(\alpha=2)$ の近傍 に実験值がプロットされることになる。しかしながら，上記の通り， 


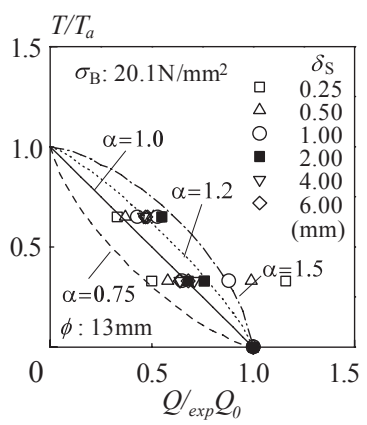

(a) $\phi=13 \mathrm{~mm}$

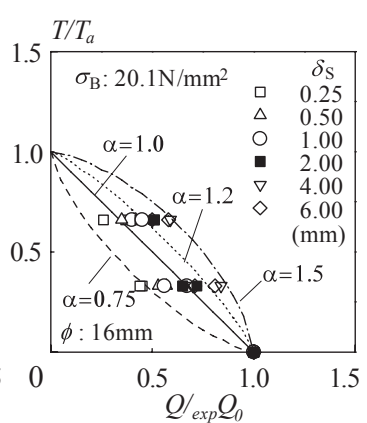

(b) $\phi=16 \mathrm{~mm}$

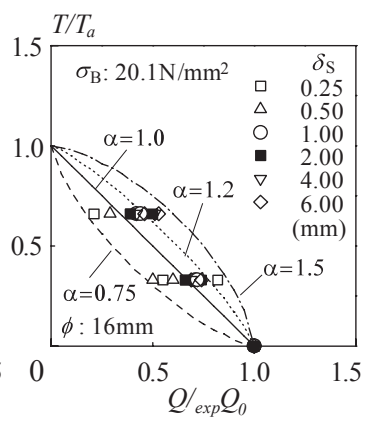

(c) $\phi=19 \mathrm{~mm}$

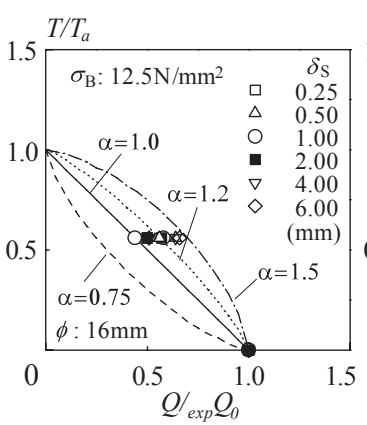

(d) $\sigma_{B}=12.5 \mathrm{~N} / \mathrm{mm}^{2}$

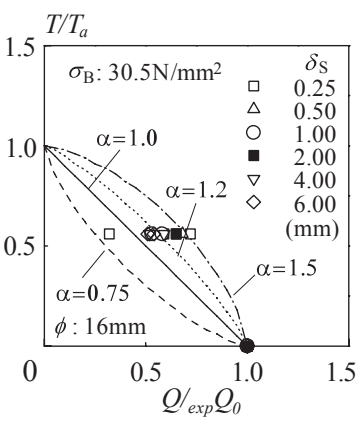

(e) $\sigma_{B}=30.5 \mathrm{~N} / \mathrm{mm}^{2}$

Fig.10 Relations between normal stress ratio and shear stress ratio

$\alpha$ の值は 1.5 以下となり, 組合せ応力が作用することで, 負担し得る 応力が小さくなったと判断される。

以上を鑑みると, 一般に外付け耐震補強の設計 ${ }^{4)}$ で採用されるよ うなずれ変形の範囲 $\left(\delta_{\mathrm{s}}=1 \sim 2 \mathrm{~mm}\right)$ では, 既往の設計方法と同様に $\alpha=1 \sim 1.5$ とすることで, 組合せ応力時の引張応力とせん断応力の負 担割合を評価できる。

\section{4. 組合せ応力を受けるあと施エアンカーの仕事量}

組合せ応力を受けるあと施工アンカーの構成則を構築する際に, 4 成分 (変位量 $\delta_{5}, \delta_{\mathrm{N}}$ と応力 $\mathrm{Q}, \mathrm{T}$ ) のうち, 2 つの既知の值 (本実験 では $\left.\delta_{\mathrm{S}}, \mathrm{T}\right)$ から, 残りの未知数 $\left(\delta_{\mathrm{N}}, \mathrm{Q}\right)$ を求めるためには, 最低で も 2 つの条件式が必要である。前 3 章では, 式 (1) に示すように軸応 力比とせん断応力比の関係について検証したが，もう一つ別の視点 による考察が必要である。既往の研究において, 望月ら ${ }^{91}$ が仕事量 を用いてプレキャスト接合部の耐力式を構築していることから, 著 者らもこれを参考にして, 仕事量の観点から本実験結果を観察する。

\section{1 接合部における仕事量の定義}

Fig. 11 に接合部が負担する仕事量の定義を示す。本実験では, 引 張荷重とせん断荷重の 2 種類の外力があることから，仕事量もそれ ぞれについて定義される。せん断荷重による仕事量を $W_{\mathrm{S}}$, 引張荷重 による仕事量を $W_{N}$ とすると，それぞれ次式により表される。

$$
\begin{aligned}
& W_{S}=\int Q d \delta_{S} \\
& W_{N}=\int T d \delta_{N}
\end{aligned}
$$

また，せん断力方向と引張力方向は，目開き量およびずれ変形と 各々直交するため, 全仕事量 $W$ はこれらを加算して得られる。

$$
W=W_{S}+W_{N}
$$

本論文では，まずは組合せ応力を受けるあと施工アンカーの基礎 的な力学挙動について論じることとし, 処女載荷時の挙動に着目す る。そのため, せん断方向の仕事量は, Fig. 11(a)に示すように, Q- $\delta_{\mathrm{S}}$ の包絡曲線, および $\delta_{\mathrm{S}}$ 軸で囲まれた領域の面積となる。 $\delta_{\mathrm{N}}$ も処 女載荷時の值を用い, $\delta_{\mathrm{S}}$ と $\delta_{\mathrm{N}}$ の関係は前傾の Fig. 9 の通りである。

\section{2 各試験体の仕事量}

Fig. $12(\mathrm{a}) \sim(\mathrm{m})$ に各試験体の仕事量 -ずれ変形 $\delta_{\mathrm{s}}$ 関係を示す。 はじめに, Fig. 12 (a), (d), (f), (i) および (k) に示す, $r_{N}=0$ の試 験体の仕事量を観察すると, これらの試験体は $\mathrm{T}=0 \mathrm{kN}$ であるため, 当然ながら $W_{N}=0 \mathrm{kN} \cdot \mathrm{mm}$ であり $W=W_{\mathrm{S}}$ となる。また Fig. $12(\mathrm{~b}) ，(\mathrm{~g})$ および (1) に示す, $r_{N}=0.33$ とした試験体では, 引張応力の導入によ

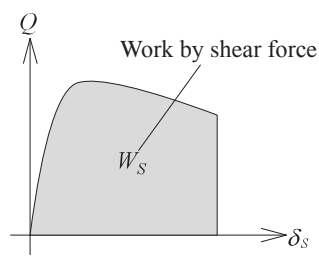

(a) $W_{\mathrm{S}}$

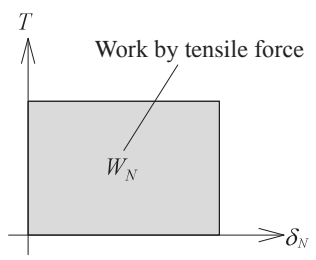

(b) $W_{N}$
Fig.11 Image of work

$W_{N}$ が生じるが, $W_{\mathrm{S}}$ の方が支配的である。しかしながら， $\mathrm{r}_{\mathrm{N}}$ を $0.56 \sim 0.66$ に設定した Fig. 12 (c)，（h）および (m) の試験体の結果を観察する と， $W_{\mathrm{S}}$ よりも $W_{N}$ の割合いが大きくなる。この傾向は， $\sigma_{\mathrm{B}}$ を違えた Fig. 12 (e) と（j）の試験体の結果を観察しても同様である。

次に各試験体の $W$ の值に着目する。Fig. 12 を網羅的に眺めると, $\phi$ が同じであれば， $r_{N} を 0.6$ 前後とした試験体が，Wが最も大きい。 ここで，全仕事量を評価することに焦点を当てることから，変位に ついてもせん断力方向と引張力方向の総和として捉える必要がある と考え, 次式で表される変位ベクトルの大きさ $|\vec{\delta}|$ を使って, 各試験 体の $W$ を比較する。

$$
|\vec{\delta}|=\sqrt{\delta_{S}^{2}+\delta_{N}^{2}}
$$

Fig. 13 に, $W-|\vec{\delta}|$ 関係を示す。 $|\vec{\delta}|$ は絶対值であるため，負の值に はならないが，同図では便宜的に負側の挙動において，x軸の值を反 転して表示している。Fig. 13 より，| $|\vec{\delta}|$ を基準にして $W$ の推移を観察 すると，Wはほぼ $|\vec{\delta}|$ に比例していることが分かる。また Fig. 13 (a) 〜 (c) より, $W$ の值は大きい方から $r_{N}=0.66, r_{N}=0, r_{N}=0.33$ の試験 体の順となっており， $r_{N}$ の大小関係による定性的な傾向は窥えない。 しかし，その大きさに顕著な差異は認められない。したがって，W は引張力の值に拠らず概ね同じ值を示すと捉えても，特段に大きな 問題はなさそうである。この特徴は， $\sigma_{B}$ を違えた Fig. $13(\mathrm{~d})$ からも 理解できる。即ち，あと施工アンカーが負担し得る仕事量は， $|\vec{\delta}|$ が 同じ大きさであれば負担する引張応力が異なっても，ほとんど変わ らないと言う事実が明らかになった。

なお，QおよびTを合成して負担応力もべクトル表記し，この絶 対值と $|\vec{\delta}|$ を用いて $W$ を算出することも可能である。しかしながら本 研究の次のステップにおいて, 力学モデルを構築する際に, $W$ の積 分を展開する作業が予測され，できるだけ簡便な式であることが望 ましいことから，本論文では $\mathrm{Q}$ と Tを分けて $W$ を算出している。

\section{3 全仕事量 $W$ の推定}

前 4.2 節の検証の結果から, 組合せ応力を受けるあと施工アンカー の全仕事量 $W$ は, 式 (7) に示すように, 単純な一次関数で表すこと 


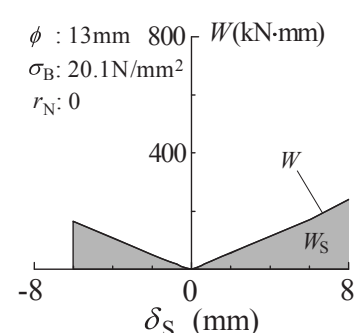

(a) D13-T000-20

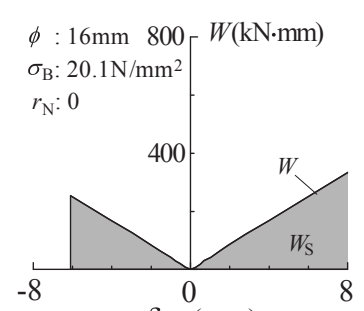

$\delta_{\mathrm{S}}(\mathrm{mm})$

(f) D 16-T000-20

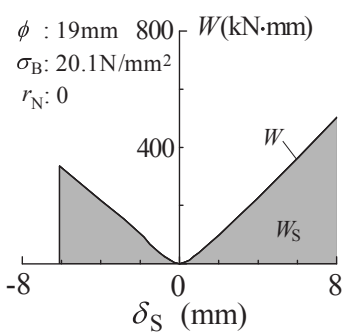

(k) D 19-T000-20

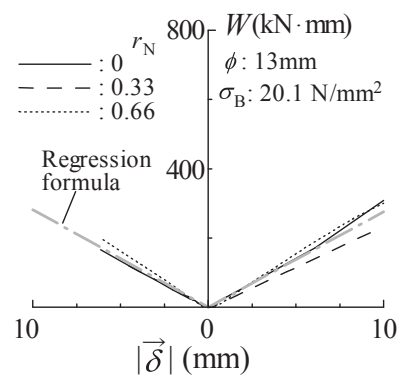

(a) $\phi=13 \mathrm{~mm}$

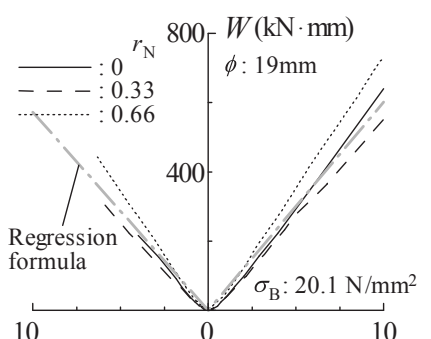

$|\vec{\delta}|(\mathrm{mm})$

(c) $\phi=19 \mathrm{~mm}$

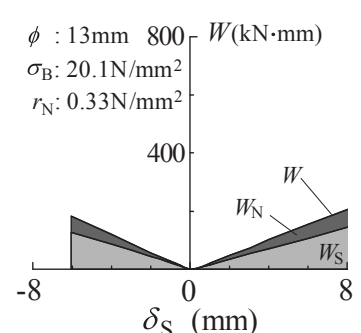

(b) D 13-T033-20

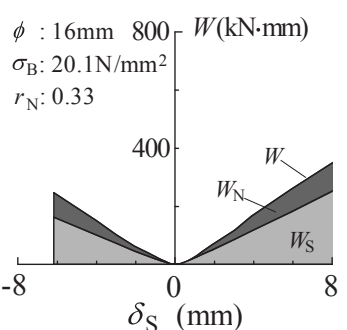

(g) D 16-T 033-20

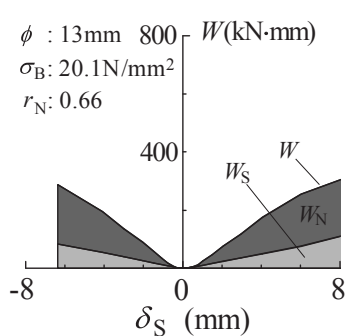

(c) D 13-T066-20

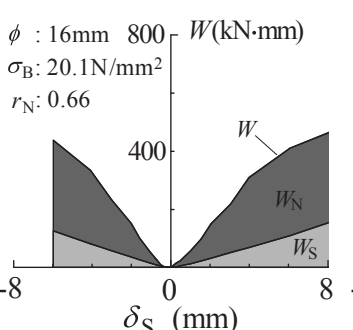

(h) D 16-T066-20

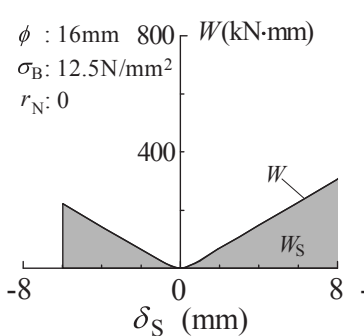

(d) D 16-T000-10

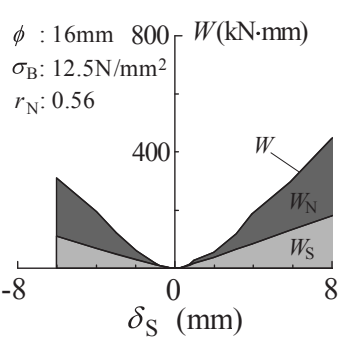

(e) D 16-T056-10

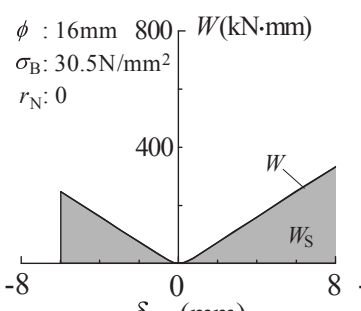

$\delta_{\mathrm{S}}(\mathrm{mm})$

(i) D 16-T000-30

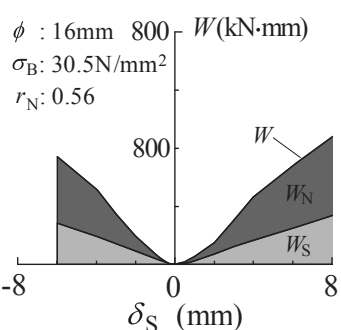

(j) D 16-T056-30

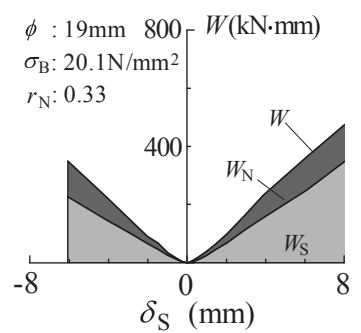

(l) D 19-T033-20

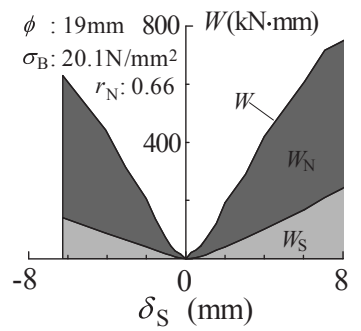

(m) D 19-T 066-20
Fig.12 Energy-Slip curves

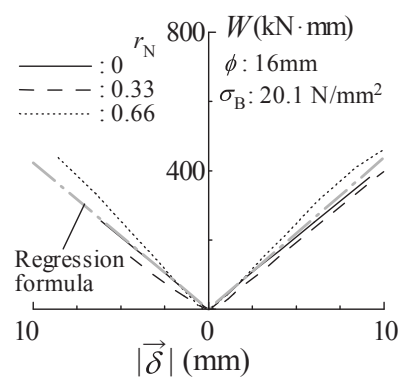

(b) $\phi=16 \mathrm{~mm}$

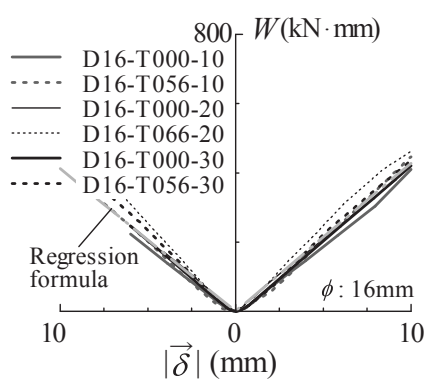

(d) Various $\sigma_{B}$
Fig.13 Energy- $|\vec{\delta}|$ curves

が可能である。

$$
W=K_{W} \times|\vec{\delta}|
$$

ここに， $\mathrm{K}_{W}$ は変位ベクトルの絶対值を仕事量に換算するための実 験係数であり, Fig. 13 における回帰直線の傾き（回帰係数）に相当

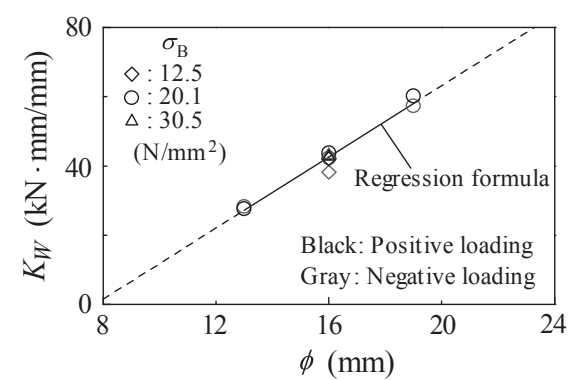

Fig.14 Relation between $K_{w}$ and $\phi$

する。さらにFig. 14 に, $\mathbf{K}_{W}$ と $\phi$ を比較した結果を示す。Fig. 14 より, $\mathrm{K}_{W}$ は $\phi$ とも, 一次直線で結ばれ得ることが理解できる。そこで, 最 小二乗法を用いて, $K_{W}$ をの一次関数で表すと下式が得られる。

$$
K_{W}=5.1 \times \phi-40(13 \mathrm{~mm} \leq \phi \leq 19 \mathrm{~mm})
$$

この式 (8) は, $\sigma_{B}=20.1 \mathrm{~N} / \mathrm{mm}^{2}$ の試験体を対象に分析した結果であ る。しかし， 3.1 節および 3.2 節の考察および Fig. 13(d) の結果より， 本実験の範囲では $\sigma_{\mathrm{B}}$ による顕著な違いが見られなかったため， $\sigma_{\mathrm{B}}$ が 異なった場合でも，同じ式で $\mathrm{K}_{W}$ を表し得るものと判断する。

ここで，上述してきた式(3) (8) を整理すると，下式が導かれる。

$$
W=\int Q d \delta_{S}+\int T d \delta_{N}=(5.1 \phi-40) \sqrt{\delta_{S}^{2}+\delta_{N}^{2}}
$$

この式 (9) は，端的に言えば組合せ応力を受けるあと施工アンカー の負担応力 $(\mathrm{Q}, \mathrm{T})$ と変位量 $\left(\delta_{\mathrm{S}}, \delta_{\mathrm{N}}\right)$ の関係を結ぶ方程式である。

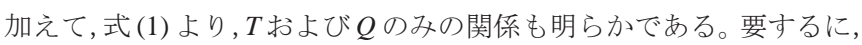
$\mathrm{Q}, \mathrm{T}, \delta_{\mathrm{s}}, \delta_{\mathrm{N}}$ の 4 成分を結びつける構成則を構築することを最終的 
な目標の一つに掲げ，本実験結果を考察してきたが，その結果とし て，本論文では $2 つ の$ 条件式を提示したことになる。これらにより, いずれか $2 つ の$ 值が既知となれば，残りの未知の值を求めることが 可能であると理解される。そこで後続の研究では, 著者らが既に提 案している純せん断状態 $(T=0)$ のモデル ${ }^{10), 11)}$ を改良し, 組合せ応力 を受けるあと施工アンカーの力学モデルを構築したいと考えている。

\section{5. 結論}

本論文では，一定引張応力を与えた接着系あと施工アンカーの正 負交番繰り返しせん断載荷実験を行い, 組合せ応力下における接着 系あと施工アンカーの力学的性質について考察した。以下に, 本論 文で得られた知見を列記する。

1）あと施工アンカーに作用する引張応力 Tが大きくなるほど，せん 断応力 $\mathrm{Q}$ が低下し，目開き量 $\delta_{\mathrm{N}}$ が大きくなる。

$2)$ 軸応力比 $\left(T / T_{a}\right)$ とせん断応力比 $\left(Q / Q_{a}\right)$ の総和関係を示す本論文の 式 (1) において, $\alpha=0.75 \sim 1.5$ とすることで, 組合せ応力下におけ る負担応力を評価できる。また， $\delta_{\mathrm{s}}$ が $1 \mathrm{~mm}$ 以上の領域では，概 ね $\alpha=1.0 \sim 1.5$ の範囲に納まる。

3) 引張応力比 $r_{N}$ が 0.33 程度であれば, せん断応力方向の仕事量が支 配的であるが， $r_{N}$ が 0.6 程度になると，引張応力方向の仕事量が 支配的となる。

4) 包絡曲線を対象とした全仕事量 $W$ は, 変位ベクトルの大きさ $|\vec{\delta}|$ と ほぼ比例関係にあり，また引張応力 Tに関わらず，概ね一定の值 となる。また，本実験で用いたアンカー筋の材質は全て SD 345 で あるが，この条件において，Wはコンクリート圧縮強度 $\sigma_{\mathrm{B}}(お よ$ そ $\left.10 \mathrm{~N} / \mathrm{mm}^{2} \leqq \sigma_{B} \leqq 30 \mathrm{~N} / \mathrm{mm}^{2}\right)$ に対しても，それほど大きな影響 を受けない。

5) 上記 4) で述べた $W$ と $|\vec{\delta}|$ の比例関係において, この比例定数 $\mathrm{K}_{W}$ を アンカー筋径 $\phi(13 \mathrm{~mm} \leqq \phi \leqq 19 \mathrm{~mm})$ の一次関数で表し得ること を示した。加えて, 負担応力 $(\mathrm{Q}, \mathrm{T})$ と変位量 $\left(\delta_{\mathrm{S}}, \delta_{\mathrm{N}}\right)$ の関係を 結ぶ方程式 (本論文の式 (9)) を提案した。

本論文における考察より，仕事量の概念を導入することで，組合 せ応力下における接着系あと施工アンカーの力学挙動を論じられる 可能性が高いことが明らかになった。また, 本論文では限定された 工法の接着系あと施工アンカーを対象に検証を行ってきたが，アン カー筋と既存躯体の定着部の付着特性を考慮することで, 工法を違 えたあと施工アンカーや先付けアンカーにも応用できると考えてい る。今後，著者らは本論文で得られた知見に基づいて，組合せ応力 を受けるあと施工アンカーの力学モデルを構築するとともに, 多数 回繰り返した場合や，定着部の付着特性の影響などについても検証 し, 本研究をさらに発展させる予定である。

\section{謝辞}

本研究の一部は, 東京工業大学フロンティア材料研究所の平成 28 年度共同利用研究, および科学研究費（代表：高瀬裕也, 課題番号 : 16K 18195）において実施しました。また本実験は，筆頭著者が飛島 建設株式会社技術研究所に在籍している際に, 同施設を利用して行 いました。最後に, 本研究の実施に際し, 室蘭工業大学・平成 28 年 度卒論生の市川大稀君には, 多大なるご協力を賜りました。ここに, 深い感謝の意を表します。

\section{参考文献}

1) 日本建築防災協会 : 2001 年改定版 既存鉄筋コンクリート造建築物の耐震改 修設計指針・同解説 , 2001. 9.1(2001 年改定版第 7 刷 )

2) 白井佑樹, 山田哲, 坂田弘安, 島田侑子, 吉敷祥一: 組合せ荷重を受けるアン カーボルトと周辺コンクリートの力学挙動に関する実験的研究, 日本建築学 会構造系論文集, Vol.80, N 0.717, pp.1735-1744, 2015. 11

3) 森下泰成, 大谷恭弘, 宮野鼻一裕, 宮川和明, 奥田香二 : 外付け而震補強工法に おける間接接合部の組合せ荷重かでの剛性評価とモデル化, 平成 19 年度日本 建築学会近畿支部研究報告集,pp.345-348, 2007

4) 日本建築防災協会 : 既存鉄筋コンクリート造建築物の「外側耐震改修マニュ アル」-枠付き鉄骨ブレースによる補強 -, 2009. 10. 20 (初版 3 刷 )

5) 瀬戸口英恵, 阿部隆英, 高瀬裕也, 佐藤眞一郎, 高橋宗臣, 佐藤貴志 : 湿式コア ドリル工法によるあと施工アンカーの性能確認実験（その 2) 注入式アンカー を用いた付着性能実験, 日本建築学会大会学術講演梗概集, 構造 IV, pp.149150,2010

6) 中野克彦, 松崎育弘, 杉山智昭 : 接着系あと施工アンカーの基本平均付着強度 に関する実験的研究, 日本建築学会大会学術講演梗概集, 構造 IV, pp.149-150, 2009

7) 瀧口克己 : 「組合せ荷重を受けるアンカーボルトと周辺コンクリートの力学挙 動に関する実験的研究」に対する討論, 日本建築学会構造系論文集, Vol.81, N 0.725 , pp.1173-1174, 2016. 7

8) 白井佑樹, 山田哲, 坂田弘安, 島田侑子, 吉敷祥一: 瀧口克己の討論に対する回 答, 日本建築学会構造系論文集, Vol.81, No.725, pp.1175-1176, 2016.7

9) 望月重, 槇谷栄次, 永坂具也 : 壁式プレキャスト構造鉛直接合部のせん断耐 力 ダウエル効果および圧縮拘束力を考慮した場合, 日本建築学会構造系論 文報告集, N 0.424, pp.11-22, 1991. 6

10) 高瀬裕也, 和田俊良, 池田隆明, 篠原保二: 繰り返しせん断力を受ける接着 系あと施工アンカーの力学モデル, 日本建築学会構造系論文集, No.682, pp.1926-1935, 2012. 12

11) 高瀨裕也 , 和田俊良, 篠原保二 : 多数回繰り返しせん断力を受ける接着系あと 施工アンカーの力学挙動に関する考察, コンクリート工学年次論文集 , Vol.37, No.2, pp.913-918, 2015

12) 日本建築学会 : 各種合成構造設計指針,pp.258-259, 2010.11（第 2 版第 1 冊）

注

注1) Table A-1に本試験体で用いた接着系あと施エアンカーの引張耐力を示し, 以下に，ここで用いた耐力式 ${ }^{12)}$ を記述する。

$$
\begin{aligned}
& p_{1}={ }_{s} \sigma_{p a} \times{ }_{s c} a \\
& p_{3}=10 \sqrt{F_{c} / 21} \times \pi \times d_{a} \times l_{c e}
\end{aligned}
$$

ここに $\mathrm{p}_{1}$ はアンカー筋の降伏で決まる耐力, $\mathrm{p}_{3}$ は接着剤の付着破壊で 決まる耐力である。また, ${ }_{5} \sigma_{\mathrm{pa}}$ はアンカー筋の降伏強度 $\left(\mathrm{N} / \mathrm{mm}^{2}\right),{ }_{\mathrm{sc}} \mathrm{a}$ は アンカー筋の有効断面積 $\left(\mathrm{mm}^{2}\right), \mathrm{F}_{\mathrm{c}}$ はコンクリートの設計基準強度（こ こでは， $\sigma_{\mathrm{B}}$ と読み替える） $\left(\mathrm{N} / \mathrm{mm}^{2}\right) ， \mathrm{~d}_{\mathrm{a}}$ はアンカー筋の軸部径 $(\mathrm{mm}), \mathrm{I}_{\mathrm{ce}}$ は強度算定用埋め込み長さ $\left(\mathrm{I}_{\mathrm{e}}-2 \mathrm{~d}_{\mathrm{a}}\right)$ である $(\mathrm{mm})$ 。

Table A-1 から理解できるよう, 引張耐力は全てアンカー筋の降伏で決 まっており，このことから本論文の式 (2) において, $\mathrm{T}_{\mathrm{a}}$ の值として $\mathrm{p}_{1}$ に 相当する式を用いることが妥当である。

\begin{tabular}{|c|c|c|c|c|c|}
\hline $\begin{array}{c}\mathrm{d}_{\mathrm{a}} \\
(\mathrm{mm})\end{array}$ & $\begin{array}{c}\mathrm{I}_{\mathrm{e}} \\
(\mathrm{mm})\end{array}$ & $\begin{array}{c}\sigma_{\mathrm{B}} \\
\left(\mathrm{N} / \mathrm{mm}^{2}\right)\end{array}$ & $\begin{array}{c}\sigma_{\mathrm{y}} \\
\left(\mathrm{N} / \mathrm{mm}^{2}\right)\end{array}$ & $\begin{array}{c}\mathrm{p}_{1} \\
(\mathrm{kN})\end{array}$ & $\begin{array}{c}\mathrm{p}_{3} \\
(\mathrm{kN})\end{array}$ \\
\hline 13 & \multirow{5}{*}{$10 d_{a}$} & 20.1 & 375 & 47.5 & 83.1 \\
\hline \multirow{3}{*}{16} & & 12.5 & \multirow{3}{*}{396} & \multirow{3}{*}{78.7} & 99.3 \\
\hline & & 20.1 & & & 125.9 \\
\hline & & 30.5 & & & 155.1 \\
\hline 19 & & 20.1 & 402 & 115.2 & 179.3 \\
\hline
\end{tabular}

Table A-1 Tensile strength of post-installed anchors used in the tests

$\mathrm{d}_{\mathrm{a}}$ : Diameter of anchor bolt, $\mathrm{l}_{\mathrm{e}}$ : Embedded length of anchor bolt, $\sigma_{B}$ : Compressive strength of concrete, $\sigma_{\mathrm{y}}: Y$ ield Strength 


\title{
MECHANICAL BEHAVIOUR AND WORK OF ADHESIVE POST-INSTALLED ANCHORS SUBJECTED TO CYCLIC SHEAR FORCE AND CONSTANT TENSILE FORCE
}

\author{
Yuya TAKASE ${ }^{* 1}$, Toshinaga WADA*2, Takaaki IKEDA*3, \\ Yasuji SHINOHARA*4 and Mitsuo MIZOGUCHI ${ }^{* 5}$
}

\footnotetext{
${ }^{* 1}$ Assoc. Prof., College of Environmental Technology, Muroran Institute of Technology, Ph. D.

*2 Prof., Dept. of Architecture, Hokkaido Polytechnic College, Dr. Eng.

*3 Prof., Dept. of Civil and Environ. Eng., Nagaoka University of Technology, Dr. Eng.

${ }^{*}$ Assoc. Prof., Laboratory for FIRST, Tokyo Insutitute of Technology, Dr. Eng.

${ }^{* 5}$ Prof., College of Environmental Technology, Muroran Insutitute of Technology, Dr. Eng.
}

\begin{abstract}
A seismic retrofitting method that uses a newly expanded frame has recently gained popularity. For the joints of structures used in seismic retrofitting, post-installed adhesive anchors are generally used. For rigidly connecting such a newly expanded frame to an existing frame, a design of the joint is very crucial because the joints are subjected to shear and tensile forces during an earthquake. However, the behavior of the anchors under combined forces remains unclear. To address this issue, herein, we conducted cyclic shear loading tests on 13 anchor bolt specimens under constant tensile force.

In Chapter 2, the details of the test plan are explained. The test parameters considered were as follows: the anchor bolt diameter $\phi$ of $13-19 \mathrm{~mm}$ as well as tensile force $T$ and concrete compressive strength $\sigma_{\mathrm{B}}$ of $10-30 \mathrm{~N} / \mathrm{mm}^{2}$. We used the tensile force ratio $r_{N}\left(\sigma_{N} / \sigma_{y}\right)$ as an index of the tensile force, and it ranged from 0 to 0.66 . $\sigma_{N}$ and $\sigma_{y}$ are the tensile stress and the yield strength of the anchor bolts.

In Chapter 3, the test results are described. First, we observed the relations of shear force Q and joint opening $\delta_{\mathrm{N}}$ with slip $\delta_{\mathrm{s}}$. The results indicated that the shear force reduces and the joint opening increases as the tensile force increases.

Second, we investigated the allowable tensile and shear forces under the combined force using Equation (S1) which is used for a Structural design ${ }^{6)}$.
\end{abstract}

$$
\left(T / T_{a}\right)^{\alpha}+\left(Q / Q_{a}\right)^{\alpha}=1
$$

Where, $T$ is the allowable tensile force, $Q$ is the allowable shear force, $T_{a}$ is the allowable tensile force when $Q=0 \mathrm{kN}, Q_{a}$ is the allowable shear force when $T=0 \mathrm{kN}$ and $\alpha$ is a coefficient, usually ranging $1-2$. A ccording to the test results, the range of $\alpha$ was $0.75-1.5$.

In Chapter 4, we use the test results to investigate the work of post-installed anchors. We found that the total work was almost constant even at varying tensile force. In addition, we proposed an estimation formula of the total work, given by the equation (S2).

$$
W=\int Q d \delta_{S}+\int T d \delta_{N}=(5.1 \phi-40) \sqrt{\delta_{S}^{2}+\delta_{N}^{2}}
$$

In Chapter 5, the conclusions were described. Findings obtained in this study were as follows:

1) The shear force was decreased and the joint opening increased as the tensile force increased.

2) For the relation between $T / T_{a}$ and $Q / Q_{a}$, the test results were reasonably estimated by choosing $\alpha$ in the range 0.75 to 1.5 .

3) $W_{\mathrm{s}}$ was dominant in the case of $r_{N}=0.33$, but $W_{N}$ was higher than $W_{\mathrm{s}}$ in the case of $r_{N}=0.56-0.66$.

4) The total work was proportional to the absolute value of the displacement vector and was not significantly influenced by the concrete compressive strength in this tests.

5) A formula for estimating the energy absorption of post-installed anchors under a combined force was proposed. Improvements to the proposed model in future studies will focus on considering bond stress-slip behavior of adhesives. 